\author{
사료내 희토 첨가가 비육돈의 생산성, 혈액내 면역관련 세포수, \\ 육질특성 및 분 중 악취방출 가스함량에 미치는 영향 \\ 신승오 · 유종상 · 이제현 · 장해동 · 김효진 · 황 염 · 진영걸 · 조진호 · 김인호 \\ 단국대학교 동물자원학과
}

\title{
Effects of Rare Earth Supplementation on Growth Performance, Blood Immune-Related Cell Population, Meat Quality and Fecal Odor Emission Gases in Finishing Pigs
}

\author{
Seung Oh Shin, Jong Sang Yoo, Je Hyun Lee, Hae Dong Jang, Hyo Jin Kim, Yan Huang, \\ Ying Jie Chen, Jin Ho Cho and In Ho Kim \\ Department of Animal Resource \& Science, Dankook University
}

\begin{abstract}
This study was conducted to evaluate effects of dietary rare earth on growth performance, blood immunerelated cell population, meat quality and fecal odor emitting gases in finishing pigs. The total of sixty four (Landrace $\times$ Yorkshire $\times$ Duroc) pigs $(65.42 \pm 1.16 \mathrm{~kg}$ in average initial body weight) were used for feeding trial during 10 weeks of experimental period. Dietary treatments included 1) NC (antibiotic free diet), 2) PC (NC diet +6 weeks 44ppm of tylosin/ 4 weeks 22ppm of tylosin) 3) RE1 (NC diet $+100 \mathrm{ppm}$ of RE), 4) RE2 (NC diet $+200 \mathrm{ppm}$ of RE). There were four dietary treatments with four replicate pens per treatment and four pigs per pen. During the overall periods, there were no significant differences in ADG (Average daily gain), ADFI (Average daily feed intake) and gain/feed ratio among treatments $(P>0.05)$. Dry matter and nitrogen digestibility were higher in RE2 treatment group than other groups $(P<0.05)$. Also, energy digestibility was higher in RE2 treatment group than PC and RE1 treatment groups $(P<0.05)$. At the 6th week WBC (white blood cell) was significantly increased $(P<0.05)$ in RE1 treatment group than NC and RE2 treatment groups. $L^{*}$ value of $M$. logissimus dorsi muscle color was significantly increased $(P<0.05)$ in rare earth supplemented groups compared to NC treatment group $(P<0.05)$. However, $\mathrm{a}^{*}$ value was lower in RE1 treatment group than PC treatment group $(P<0.05)$. In fatty acid composition of Intramuscular fat, total MUFA was significantly higher in RE2 treatment group than other groups $(P<0.05)$. Also, total UFA was significantly increased in RE2 treatment group compared with NC and PC treatment groups $(P<0.05)$. In fatty acid composition of back fats, total SFA of rare earth supplemented groups were lower than in PC treatment group $(P<0.05)$. UFA:SFA ratio was significantly higher in rare earth supplemented groups than PC treatment group $(P<0.05)$. In fecal odor emission, $\mathrm{NH}_{3}$ was significantly decreased $(P<0.05)$ in rare earth supplemented groups compared to NC and PC treatment groups. In conclusion, the results of the experiment was affected by rare earth supplementation on digestibilities, meat quality, fatty acid and fecal odor emission gases in finishing pigs.

(Key words : Rare earth, Growth performance, Meat quality, Fatty acid, Fecal odor emission gases, Finishing pigs)
\end{abstract}

Corresponding author : Dr. In Ho Kim, Dept. of Animal Resource \& Science, Dankook University \#29 Anseodong, Cheonan, Choongnam 330-714, Korea

Tel : 041-550-3652, Fax : 041-550-3604, E-mail : inhokim@dankook.ac.kr 


\section{I. 서 론}

희토 (稀土, Rare Earth, RE)는 일반적으로 Lanthanides라고도 하며, 희토 원소의 약칭으로 라탄족 원소 15 개와 이와 성질이 비슷한 스칸 듐 $(\mathrm{Se})$ 과 이트륨 $(\mathrm{Y})$ 을 포함한 17 개의 원소로 구성된 원소들을 총칭한다. 희토 (RE)는 1787년 스웨덴 (Sweden)의 희소한 광물에서 발견되었으 며, 전형적인 금속원소로서 자연계에 널리 분 포되어 있으나 세계의 몇 국가에만 집중적으로 분포되어 있다. 전 세계 매장량의 $76 \%$ 가 중국 에 매장되어 있다(Shang and Liu, 1997).

희토는 $4 \mathrm{f}$ 전자구도를 갖는 독특한 화학적 특성을 가지고 있으며, 일부 원소들은 고유한 생물학적 기능을 가지고 있어 축산업, 농업, 의 약분야 등 다양한 분야에서 희토의 이용성 및 효과에 대한 연구가 활발히 진행되고 있다 (Hirano와 Suzuki, 1996; Deveci 등 2000).

가축의 사료 첨가제로서 희토의 급여는 돼 지, 가금, 비육우 등의 다양한 축종에서 성장촉 진의 효과가 있으며 (Wang, 1989), 체내 효소의 활력을 높여주는 조효소의 역할 (He 등, 2003), 장내 박테리아의 활성화 및 호르몬의 활동 촉 진 (Xie 등, 1991) 및 소화율과 영양소 이용율의 향상 (Cheng 등, 1994; Lu와 Yang, 1996) 등 여 러 연구 결과가 보고된바 있다.

돼지에 대한 희토의 연구는 1990년대부터 활 발하게 진행되었으며, 돼지에 있어서는 주로 생산성에 미치는 영향에 관한 연구들이 진행되 어왔다. 희토는 단백질 대사에 촉매를 돕는 작 용 및 효소의 활성을 증가시키는 효과가 있어 (胡, 1999), 돼지의 생산성을 향상시키며, 설사 예방 및 폐사율을 낮추는 효과가 있다고 하였 다. 또한, 김 (2004)의 연구에서 희토의 첨가급 여는 자돈에서는 폐사율을 감소시키고 비육돈 에서는 도체율을 개선시키며, 등지방 두께를 얇아지게 한다고 하였다. Wan 등(1997)의 연구 에서도 비육돈에 희토 첨가 급여시 증체량 및 사료요구율의 개선, 육질개선, 살코기와 도체율 을 증가시켰다고 하였다.

희토의 사료 첨가 효과는 희토의 원소 종류, 화학적 형태, 첨가수준에 따라 다르게 나타나
며, 유전적 영향이 적은 경우에는 희토의 첨가 효과가 더욱 크게 나타날 수 있다고 하였다 (Shang과 Liu, 1997; $\mathrm{He}$ 등 2003). 적정 수준의 희토 첨가는 생산성 개선의 효과가 있으나, 희 토의 수준이 너무 높으면 생장과 발육에 악영 향을 미치며, 낮은 경우 희토 첨가에 의한 효 과가 없다고 하였다 (張 등, 2000).

희토에 관한 연구들은 주로 중국에서 이루어 졌으며, 국내에서의 희토에 관한 연구는 미흡 한 실정이다. 국내 사육환경, 영양소 급여수준 및 품종 등이 중국과 상이하여 희토의 첨가 효 과가 다르게 나타날 가능성이 있으므로, 보다 구체적인 희토의 첨가 효과를 규명하기 위해서 는 국내 사육환경 여건에 적합한 연구가 필요 할 것으로 사료된다.

따라서, 본 연구에서는 희토를 비육돈 사료 내 첨가하여 생산성, 면역관련 세포수, 육질특 성 및 분내 유해가스 함량에 미치는 영향을 알 아보기 위하여 시험을 실시하였다.

\section{ㅍ. 재료 및 방법}

\section{1. 시험동물 및 시험설계}

시험 개시시 체중이 $65.42 \pm 1.16 \mathrm{~kg}$ 인 3원 교 잡종 (Landrace×Yorkshire×Duroc)의 비육돈 64 두 를 공시하였으며, 10 주간 사양시험을 실시하였 다.

시험설계는 1) Antibiotic free diet (NC), 2) NC diet +6 weeks $44 \mathrm{ppm}$ of tylosin $/ 4$ weeks 22 ppm of tylosin (PC) 3) NC diet $+100 \mathrm{ppm}$ of RE (RE1) 및 4) $\mathrm{NC}$ diet $+200 \mathrm{ppm}$ of RE (RE2)로 4 개 처리를 하여 처리당 4 반복, 반복당 4 두씩 완전임의 배치하였다.

\section{2. 시험관리}

사양시험은 $1.8 \times 1.8 \mathrm{~m}$ 크기의 돈방에 4 마리씩 군집 사육 하였으며, 시험사료는 NRC (1998) 요구량에 따라 배합한 옥수수-대두박 위주의 사료로서 시험사료의 조성은 Table 1 과 같다. 시험 사료는 가루형태로 자유 채식토록 하였으 
Table 1. Diet composition (as-fed basis)

\begin{tabular}{lrc}
\hline \multicolumn{1}{c}{ Ingredients (\%) } & $\begin{array}{c}\text { Phase } 1 \\
(0 \sim 6 w k s)\end{array}$ & $\begin{array}{c}\text { Phase } 2 \\
\text { (6 10wks) }\end{array}$ \\
\hline \hline Corn & 53.95 & 61.60 \\
Soybean meal & 19.40 & 13.56 \\
Wheat & 7.69 & 10.00 \\
Animal fat & 5.00 & 3.36 \\
Rice bran & - & 3.00 \\
Molasses & 3.00 & 2.50 \\
Lupin, Seed & 5.00 & 2.00 \\
Rapeseed meal & - & 2.00 \\
Canola meal & 3.00 & - \\
Tricalcium phosphate & 1.95 & 0.79 \\
Limestone & 0.13 & 0.63 \\
Salt & 0.40 & 0.25 \\
Vitamin/mineral premix ${ }^{1)}$ & 0.20 & 0.20 \\
L-lysine HCL & 0.11 & 0.06 \\
Choline Choride (25\%) & 0.11 & - \\
Antioxidant (ethoxyquin 25\%) & - & 0.05 \\
Rare earth & & 0 \\
\hline Chemical composition & & \\
ME, kcal/kg & 0 & 3,260 \\
Crude protein, \% & 3,350 & 14.00 \\
Lysine, \% & 16.60 & 0.70 \\
Calcium, \% & 0.90 & 0.60 \\
Phosphorus, \% & 0.80 & 0.50 \\
\hline & 0.70 & \\
\hline (3) & & \\
\hline
\end{tabular}

1) Supplied per kg diet: vitamin $A, 9,000 \mathrm{IU}$; vitamin $D_{3}$, 1,200 IU; vitamin E, $40 \mathrm{IU}$; vitamin $\mathrm{K}$ (menadione bisulfate complex), $3.0 \mathrm{mg}$; vitamin $\mathrm{B}_{2}, 5.2 \mathrm{mg}$; vitamin $\mathrm{B}_{6}, \quad 2.6 \mathrm{mg}$; vitamin $\mathrm{B}_{12}, 26 \mu \mathrm{g}$; niacin, $32 \mathrm{mg}$; d-pantothenic acid (as d-calcium pantothenate), $20 \mathrm{mg}$; $\mathrm{Cu}, 15$ mg; Fe, 70 mg; Zn, 50 mg; Mn, 50 mg; I, 0.5 mg; Co, $0.3 \mathrm{mg}$ and Se, $0.2 \mathrm{mg}$.

2) Abbreviated CON, basal diet; RE1, 0.05\% rare earth replaced in $0.05 \%$ corn; RE2, $0.10 \%$ rare earth replaced in $0.10 \%$ corn.

${ }^{3)}$ Calculated values.

며, 물은 자동급수기를 이용하여 자유로이 먹 을 수 있도록 조절하였다. PC 처리구는 출하 14 일전에 휴약 기간을 두어 항생제를 첨가하지 않은 antibiotic free diet를 급여하였다.

\section{3. 희토 혼합물의 성상과 성분}

희토 혼합물은 $45.93 \%$ Rare earth oxide, 15.16\% Lanthanum oxide $\left(\mathrm{La}_{2} \mathrm{O}_{3}\right), 27.76 \%$ Cerium dioxide $\left(\mathrm{CeO}_{2}\right), 2.90 \%$ Praseodymium Oxide $\left(\mathrm{Pr}_{2} \mathrm{O}_{11}\right)$ 및 $0.13 \%$ Neodymium xide $\left(\mathrm{Nd}_{2} \mathrm{O}_{3}\right)$ 의 주요 라탄 족 원소와 기타 미량 원소들의 산화혼합물로 구성되어 있으며 (Table 2), 본 시험에 첨가한 희토의 주요 성분은 산화형태의 $20.0 \%$ 희토 혼 합물과 부형제로서, $55.0 \%$ Malt powder, $12.0 \%$ Malt sprouts, $10.0 \%$ Corn starch, $1.0 \%$ saccharin 및 2.0\% 생균제 (Saccharomyces cerevsiae)를 함 유하였다 (Table 3).

Table 2. Chemical composition of RE (Rare Earth)

\begin{tabular}{lr}
\hline \multicolumn{1}{c}{ Ingredients } & \% \\
\hline \hline $\mathrm{REO}^{1)}$ & 45.93 \\
$\mathrm{La}_{2} \mathrm{O}_{3}$ & 15.16 \\
$\mathrm{CeO}_{2}$ & 27.76 \\
$\mathrm{Pr}_{6} \mathrm{O}_{11}$ & 2.90 \\
$\mathrm{Nd}_{2} \mathrm{O}_{3}$ & 0.13 \\
$\mathrm{Fe}_{2} \mathrm{O}_{3}$ & 0.04 \\
$\mathrm{SO}_{4}^{-}$ & 0.02 \\
$\mathrm{CaO}$ & 0.48 \\
$\mathrm{MgO}$ & 0.17 \\
$\mathrm{ZnO}$ & 0.02 \\
$\mathrm{Na} 2$ & 0.03 \\
Unidentified & 7.36 \\
Total & 100.00 \\
\hline
\end{tabular}

${ }^{1)}$ Rare earth oxide.

\section{4. 조사항목}

(1) 일당증체량, 일당사료섭취량 및 사료효율 체중 및 사료 섭취량은 시험 개시시, 6주 및 종료시 각각 측정하여 일당증체량, 일당사료섭 취량 및 사료효율을 계산하였다.

(2) 영양소 소화율

영양소 소화율을 측정하기 위하여 시험 표시 
Table 3. Composition of RE product

\begin{tabular}{lc}
\hline \multicolumn{1}{c}{ Ingredients } & $\%$ \\
\hline \hline RE (rare earth) & 20.0 \\
Malt Powder & 55.0 \\
Malt Sprouts & 12.0 \\
Corn Starch & 10.0 \\
Saccharin & 1.0 \\
Sacchromyces cerevisiae $\left(10^{6} \mathrm{cfu} / \mathrm{g}\right)$ & 2.0 \\
Total & 100.0 \\
\hline
\end{tabular}

물로 산화크롬 $0.2 \%$ 첨가한 시험사료를 시험 6 주 및 종료 전에 7일간 급여하여 6주 및 종료 전, 항문 마시지 법으로 분을 채취하였다. 채취 한 분은 $60^{\circ} \mathrm{C}$ 의 건조기에 72 시간 건조 시킨 후 Willey mill로 분쇄하여 분석에 이용하였다. 사 료의 일반성분과 표시물로 혼합된 $\mathrm{Cr}$ 은 $\mathrm{AOAC}$ (1995)에 제시된 방법에 의해 분석하였다.

영양소 소화율 $(\%)=\frac{\mathrm{A}-\mathrm{B}}{\mathrm{A}} \times 100$

$\mathrm{A}=100$ / (사료내 건물함량 / 사료내 크롬함량), $\mathrm{B}=100$ / (분 내 건물함량 / 분 내 크롬함량)

\section{(3) 혈액성상}

혈액채취는 각 처리당 5 마리를 임의 선발하 여 개시시, 6주 및 종료시에 각각 경정맥 (Jugular)에서 $\mathrm{K}_{3} \mathrm{EDTA}$ vacuum tube (Becton Dickinson Vacutainer Systems, Franklin Lakes, $\mathrm{NJ})$ 를 이용하여 혈액 $2 \mathrm{~mL}$ 을 채취 후 자동혈액 분석기(ADVID 120, Bayer, USA)로 WBC (White blood cell), RBC (Red blood cell) 및 Lymphocyte 를 측정하였다.

\section{(4) 육질 분석}

육질 분석에 사용된 돈육은 도축 후 $4^{\circ} \mathrm{C}$ 냉 장고에 24시간 저장 후, 각 처리구별로 8두씩 을 선별하여 반도체 등심 부위 (M. longissimus dorsi)를 분할 정형하여 분석에 이용하였다. 육 색은 Chromameter (Model CR-210, Minolta Co., Japan)를 사용하여 각 sample 당 5회 반복하여
측정하였으며, 이때 표준색판은 $\mathrm{L}^{*}=89.2, \mathrm{a}^{*}=$ $0.921, \mathrm{~b}^{*}=0.783$ 으로 하였다. 관능검사는 5 명의 관능검사요원을 구성하여 수행하였으며, National pork producers council (2000) 기준안에 의해 신 선육의 육색 (color:1 5), 근내지방도 (marbling: 1 5), 경도 (firmness:1 5)를 조사하였다. $\mathrm{pH}$ 는 도축 24시간 후에 5 번째와 6 번째 늑골 사이의 등심부위를 채취하여 $\mathrm{pH}$ meter (77P, Istek, Korea)를 이용하여 측정하였다. 등심단면적은 구적기 (MT-10S, MT precision, Japan)를 이용하 여 등심단면적을 측정하였고, 드립감량 (drip loss)은 시료를 $2 \mathrm{~cm}$ 두께의 일정한 모양으로 절단한 후 polyethylene bag에 넣어 $4^{\circ} \mathrm{C}$ 에서 6 일 간 보관하면서 발생되는 감량을 측정하였다. 가열감량 (cooking loss)은 시료를 일정한 모양 으로 절단하여 무게를 측정 후, polyethylene $\mathrm{bag}$ 에 넣고 $75^{\circ} \mathrm{C}$ 항온 수조에서 30 분간 가열하 고 상온에서 30 분간 방냉시킨 후 시료의 무게 를 측정하여 가열감량을 측정하였다. 보수력 (Water holding capacity)은 Hofmann 등 (1982)의 방법으로 전체면적과 육의 면적의 비율을 기록 하여 측정하였으며, 지방산패도 (TBARS) 분석 은 Witte 등 (1970)의 Thiobarbituric acid(TBA)가 측정법을 이용하여 분석하였다.

\section{(5) 지방산 분석}

지방 추출은 Folch 등 (1957)의 방법으로 chloroform과 methanol로 추출하였다. 시료 $10 \mathrm{~g}$ 을 시료의 5 10배 folch용액 (chloroform: methanol $=2: 1$ )에 2 시간 추출한 후 분별깔대기에 filtering 하여 담고 $0.8 \% \mathrm{KCl}$ 을 첨가하여 5 분간 혼합한 후, $3,000 \mathrm{rpm}$ 에서 10 분간 원심분리 시켰다. 하 층은 funnel filter paper에 sodium anhydrous sulfate를 첨가하고 filtering 하여 분리한 후 45 ${ }^{\circ} \mathrm{C}$ 에서 진공 농축기로 농축하여 추출하였다. 추출한 지방은 $\mathrm{NaOH} / 0.5 \mathrm{~N}$ methanol $10 \mathrm{~mL}$ 에 넣고 $80 ~ 90^{\circ} \mathrm{C}$ 에서 6 분간 반응, $14 \% \mathrm{BF}_{3} 5 \mathrm{~mL}$ 를 넣고 3 분간 반응시키고, 핵산 $10 \mathrm{~mL}$ 를 넣고 1 분간 반응시켜 냉각시킨 후 포화 $\mathrm{NaCl}$ 을 넣어 반응을 종결시킨 후 $\mathrm{GC}$ (Gas chromatography)/ FID (Flame ionization detector)로 분석하였다 (Table 4). 
Table 4. GC conditions for analysis of total fatty acids compositions

\begin{tabular}{ll}
\hline \multicolumn{1}{c}{ Items } & \multicolumn{1}{c}{ Conditions } \\
\hline \hline Instrument & Hewlett Packard 5890 series II Gas chromatography \\
Column & VARIAN CP-SIL80 (FAME) \\
Flow & $\mathrm{N} 2$ \\
Flow rate & $1 \mathrm{ml} / \mathrm{min}$ \\
Detector & FID(Flame Ionization Detector) \\
Spilt & $100: 1$ \\
Inlet Temperature & $220^{\circ} \mathrm{C}$ \\
Detector Temperature & $240{ }^{\circ} \mathrm{C}$ \\
Initial Oven Temperature & $120^{\circ} \mathrm{C}$ \\
Final oven temperature & $220^{\circ} \mathrm{C}$ \\
\hline
\end{tabular}

(6) 분내 유해가스 발생 물질 분석

분내 암모니아 $\left(\mathrm{NH}_{3}\right)$, Mercaptans $(\mathrm{R} \cdot \mathrm{SH})$, 휘 발성 지방산 및 황화수소 $\left(\mathrm{H}_{2} \mathrm{~S}\right)$ 발생량을 측정 하기 위하여 시험 종료시에 각 처리구에서 동 일한 시간동안 배설된 분을 처리당 5 마리로부 터 채취한 후, 분석에 이용하였다. 암모니아, Mercaptans, 휘발성 지방산 및 황화수소의 측정 은 시료 $300 \mathrm{~g}$ 을 취하여 $1000 \mathrm{~mL}$ 의 밀봉된 플 라스틱 용기에 넣고 24시간 발효시킨 후, 실온 에 30일 동안 보관하면서 Gastec (Model GV100, GASTEC, Japan)을 사용하여 분내 악취발 생물질 $\left(\mathrm{NH}_{3}, \mathrm{R} \cdot \mathrm{SH}, \mathrm{H}_{2} \mathrm{~S}\right.$ 및 Acetic acid)을 측 정하였다.

\section{5. 통계처리}

모든 자료는 SAS (1996)의 General Linear Model Procedure를 이용하여 분산분석을 실시하 였고, Ducan's multiple range test (Duncan, 1955) 로 처리하여 시험 처리구 평균간 차이의 유의 성 유무 여부를 검정하였다.

\section{III. 결과 및 고찰}

\section{1. 생산성}

비육돈에 있어서 희토의 첨가가 체중, 일당 증체량, 일당사료 섭취량 및 사료효율에 미치 는 영향은 Table 5에 나타내었다. 시험 6주, 종
료시 및 전체 사양시험 기간 동안의 체중, 일 당증체량, 일당사료섭취량 및 사료효율은 처리 구간에 유의적인 차이가 없었다 $(P>0.05)$.

$\mathrm{He}$ 등 (2001)과 송 (2007)은 비육돈에 희토의 첨가급여시 일당증체량과 사료요구율이 개선시 켰다고 보고하였으나, Borger (2003), Eisele (2003) 및 Kessler (2004)의 연구결과에서는 이유 자돈 및 비육돈에 150 200 ppm 수준의 chloride 형태의 희토 급여시 일당증체량은 증가하였으 나 사료효율은 감소하였다고 하였다. 또한, Böhme 등 (2002)은 비육돈에 100ppm의 chloride, nitrate, ascorbate 및 citrate 형태의 희토 급여시 일당증체량이 1.1 3.6\% 감소하였다고 하였으며, 김 (2004)은 이유자돈에 100, 200 및 $300 \mathrm{ppm}$ 의 희토를 급여한 시험에서 일당증체량과 사료요 구율이 높은 경향을 나타내었다는 보고는 본 시험의 경향과 상이하였다.

$\mathrm{He}$ 등 (2003)은 희토의 사료 첨가 효과는 희 토 원소의 종류, 화학적 형태 및 첨가 수준에 따라 달라진다고 하였으며, 각 연구에서 생산 성의 결과가 각기 다르게 나타난 원인도 이러 한 차이에 기인된 것으로 사료된다.

\section{2. 영양소 소화율}

비육돈에 있어서 희토의 첨가가 영양소 소화 율에 미치는 영향은 Table 6에 나타내었다. 건 물소화율은 RE2 처리구가 다른 처리구와 비교 하여 높게 나타났으며 $(P<0.05)$. PC 및 RE1처리 
Table 5. Effects of RE supplementation on growth performance in finishing pigs

\begin{tabular}{lccccc}
\hline Items & $\mathrm{NC}^{1)}$ & $\mathrm{PC}^{1)}$ & $\mathrm{RE1} 1^{1)}$ & $\mathrm{RE2}^{1)}$ & $\mathrm{SE}^{2)}$ \\
\hline \hline Body weight (kg) & & & & & \\
Initial weight & 65.70 & 65.20 & 64.52 & 66.55 & 0.71 \\
6 weeks & 90.86 & 94.99 & 89.45 & 92.63 & 2.37 \\
Final weight & 112.00 & 115.58 & 110.73 & 115.75 & 3.01 \\
\hline 0 6 weeks & & & & \\
ADG (kg) & 0.599 & 0.709 & 0.594 & 0.621 & 0.045 \\
ADFI (kg) & 2.019 & 2.138 & 1.988 & 2.124 & 0.051 \\
Gain/feed & 0.296 & 0.331 & 0.298 & 0.292 & 0.021 \\
6 10 weeks & & & & \\
ADG (kg) & 0.755 & 0.735 & 0.760 & 0.826 & 0.091 \\
ADFI (kg) & 2.751 & 2.636 & 2.841 & 2.606 & 0.259 \\
Gain/feed & 0.274 & 0.278 & 0.268 & 0.317 & 0.026 \\
Overall & & & & \\
ADG (kg) & 0.661 & 0.720 & 0.660 & 0.703 & 0.034 \\
ADFI (kg) & 2.312 & 2.337 & 2.329 & 2.317 & 0.114 \\
Gain/feed & 0.286 & 0.307 & 0.283 & 0.303 & 0.013 \\
\hline 1) NC: Antibiotic free diet; PC: NC diet included 0 6 weeks 44 ppm/ 6 10 weeks 22 ppm of tylosin; RE1: NC diet + RE \\
100 ppm; RE2: NC diet + RE 200 ppm. \\
2) Pooled standard error.
\end{tabular}

Table 6. Effects of RE supplementation on nutrient digestibility in finishing pigs

\begin{tabular}{lccccc}
\hline \multicolumn{1}{c}{ Items (\%) } & $\mathrm{NC}^{1)}$ & $\mathrm{PC}^{1)}$ & $\mathrm{RE}^{1)}$ & $\mathrm{RE}^{1)}$ & $\mathrm{SE}^{2)}$ \\
\hline \hline Dry matter & $71.11^{\mathrm{c}}$ & $75.06^{\mathrm{b}}$ & $75.04^{\mathrm{b}}$ & $77.99^{\mathrm{a}}$ & 0.87 \\
Nitrogen & $73.64^{\mathrm{b}}$ & $74.75^{\mathrm{b}}$ & $73.89^{\mathrm{b}}$ & $78.71^{\mathrm{a}}$ & 1.10 \\
Energy & $70.87^{\mathrm{c}}$ & $75.71^{\mathrm{ab}}$ & $74.73^{\mathrm{b}}$ & $78.20^{\mathrm{a}}$ & 0.91 \\
\hline
\end{tabular}

${ }^{1)}$ NC: Antibiotic free diet; PC: NC diet included 0 6 weeks 44ppm/ 6 10 weeks 22ppm of tylosin; RE1: NC diet + RE 100ppm; RE2: NC diet + RE 200ppm.

${ }^{2)}$ Pooled standard error.

${ }^{\mathrm{a}-\mathrm{c}}$ Means in the same row with difference superscripts differ $(P<0.05)$.

구는 $\mathrm{NC}$ 처리구와 비교하여 높았다 $(P<0.05)$. 질소 소화율은 RE2 처리구가 다른 처리구와 비 교하여 높게 나타났다 $(P<0.05)$. 에너지 소화율 은 RE2 처리구가 NC 및 RE1 처리구와 비교하 여 높았으며 $(P<0.05), \mathrm{RE} 1$ 처리구는 $\mathrm{NC}$ 처리구 와 비교하여 높았다 $(P<0.05)$.

Cheng 등 (1994)과 Lu와 Yang(1996)은 희토 원소의 첨가는 가축의 영양소 소화율을 향상 시킬 수 있다고 하였으며, Wang과 Xu (2003)은
육성돈에 희토 원소 중 하나인 lanthanum $(\mathrm{La})$ 의 급여시 성장호르몬이 획기적으로 증가하며 소화율과 영양소 이용률을 높일 수 있다고 하 였다. 또한, 胡(1999)는 육성돈 사료에 희토 첨 가시 복잡한 촉매작용과 촉매작용을 도와 효소 의 활성을 증가시킴으로써 단백질과 아미노산 의 소화율이 향상되었다고 하였다.

본 시험에서는 $200 \mathrm{ppm}$ 희토 첨가 처리구에 서 소화율의 향상 효과가 나타났으며, 이러한 
소화율의 향상은 다른 연구자들의 주장대로 성 장호르몬의 상승과 효소의 활성에 의한 결과로 사료된다.

\section{3. 혈액내 면역관련 세포수}

비육돈에 있어서 희토의 첨가가 혈액내 면역 관련 세포수에 미치는 영향은 Table 7에 나타 내었다. $\mathrm{WBC}$ 수준은 6주에서 RE1처리구가 $\mathrm{NC}$ 및 RE2 처리구와 비교하여 유의적으로 높 게 나타났으나 $(P<0.05), \mathrm{WBC}$ 의 변화량은 유의 적인 차이가 없었다 $(P>0.05)$. 전체시험 기간 동 안 RBC 및 Lymphocyte의 함량 및 변화량은 유 의적인 차이가 없었다 $(P>0.05)$.

包 (2001)는 희토원소는 하나의 생리활성제로 서 동물의 면역기능을 증강 시킨다고 하였으 며, 희토는 백혈구의 면역기능을 강화한다고 보고하였다 (紀, 2003). 또한, 吳 (2003)는 희토를
돼지 사육에 사용한 결과 각종 질병에 대한 저 항성 증진 효과가 있다고 하였다.

본 시험의 결과 면역관련 혈액학적 지표의 변화량의 차이가 나타나지 않았으나, WBC 수 준은 시험 6주에서 희토 $100 \mathrm{ppm}$ 첨가구가 대 조구 및 $200 \mathrm{ppm}$ 첨가구에 비해 높은 함량을 나타내어 첨가 수준에 따른 영향이 나타나 추 후 희토 첨가수준에 따른 면역증강 효과에 대 해 추가적인 연구가 필요할 것으로 사료된다.

\section{4. 육질 특성}

비육돈에 있어서 희토의 첨가가 육질특성에 미치는 영향은 Table 8에 나타내었다. 관능평가 결과 마블링은 $\mathrm{RE} 2$ 처리구가 $\mathrm{NC}$ 및 $\mathrm{PC}$ 처리구 와 비교하여 유의적으로 높게 나타났다 $(P<$ 0.05). 육색에 있어서 명도를 나타내는 $\mathrm{L}^{*}$ 값은 희토를 첨가한 RE1 및 $\mathrm{RE} 2$ 처리구가 $\mathrm{NC}$ 처리

Table 7. Effects of RE supplementation on change in blood biochemical profiles in finishing pigs

\begin{tabular}{|c|c|c|c|c|c|}
\hline Items & $\mathrm{NC}^{1)}$ & $\mathrm{PC}^{1)}$ & $\mathrm{RE}^{1)}$ & $\mathrm{RE}^{1)}$ & $\mathrm{SE}^{2)}$ \\
\hline \multicolumn{6}{|l|}{$\operatorname{RBC}\left(\times 10^{6} / \mu \ell\right)$} \\
\hline Initial & 6.67 & 6.63 & 6.40 & 6.79 & 0.19 \\
\hline 6 weeks & 6.72 & 6.74 & 6.20 & 6.33 & 0.22 \\
\hline Final & 6.96 & 6.94 & 6.82 & 7.04 & 0.20 \\
\hline Difference (0 42 days) & 0.29 & 0.31 & 0.42 & 0.25 & 0.10 \\
\hline \multicolumn{6}{|l|}{ WBC $\left(\times 10^{3} / \mu \ell\right)$} \\
\hline Initial & 16.93 & 17.39 & 17.90 & 14.74 & 1.30 \\
\hline 6 weeks & $15.13^{\mathrm{b}}$ & $17.52^{\mathrm{ab}}$ & $22.34^{\mathrm{a}}$ & $15.54^{\mathrm{b}}$ & 1.96 \\
\hline Final & 15.67 & 17.49 & 19.17 & 16.19 & 2.21 \\
\hline Difference (0 42days) & -1.26 & 0.10 & 1.27 & 1.45 & 0.84 \\
\hline \multicolumn{6}{|l|}{ Lymphocyte (\%) } \\
\hline Initial & 51.63 & 58.80 & 54.23 & 61.95 & 4.54 \\
\hline 6 weeks & 53.73 & 47.90 & 38.00 & 52.40 & 4.60 \\
\hline Final & 47.06 & 46.83 & 46.50 & 45.87 & 2.30 \\
\hline Difference & -4.57 & -11.97 & -7.73 & -16.08 & 5.53 \\
\hline
\end{tabular}

1) NC: Antibiotic free diet; PC: NC diet included 0 6 weeks 44 ppm/ 6 10 weeks 22ppm of tylosin; RE1: NC diet + RE 100 ppm; RE2: NC diet + RE 200 ppm.

2) Pooled standard error.

a,b Means in the same row with difference superscripts differ $(P<0.05)$. 
Table 8. Effects of RE supplementation on meat quality in finishing pigs

\begin{tabular}{lccccc}
\hline Items & $\mathrm{NC}^{1)}$ & $\mathrm{PC}^{1)}$ & $\mathrm{RE}^{1)}$ & $\mathrm{RE}^{1)}$ & $\mathrm{SE}^{2)}$ \\
\hline \hline Sensory evaluation & & & & & \\
Color & 2.33 & 2.24 & 2.11 & 2.25 & 0.09 \\
Marbling & $1.60^{\mathrm{b}}$ & $1.61^{\mathrm{b}}$ & $1.71^{\mathrm{ab}}$ & $2.06^{\mathrm{a}}$ & 0.13 \\
Firmness & 1.59 & 1.64 & 1.66 & 1.83 & 0.09 \\
\hline Meat color & & & & & \\
Lightness (L*) & $53.72^{\mathrm{b}}$ & $55.15^{\mathrm{ab}}$ & $56.35^{\mathrm{a}}$ & $56.48^{\mathrm{a}}$ & 0.60 \\
Redness (a*) & 17.59 & 18.08 & 16.21 & 16.71 & 0.19 \\
Yellowness (b*) & 6.35 & 7.17 & 6.66 & 7.11 & 0.26 \\
TBARS (mgMA/kg) & 0.019 & 0.023 & 0.016 & 0.018 & 0.005 \\
24 pH loin & $5.36^{\mathrm{ab}}$ & $5.33^{\mathrm{ab}}$ & $5.37^{\mathrm{a}}$ & $5.31^{\mathrm{b}}$ & 0.02 \\
Water holding capacity (\%) & 55.38 & 55.60 & 58.11 & 56.43 & 3.66 \\
\hline Drip loss (\%) & & & & & \\
1 days & 4.18 & 4.22 & 4.05 & 2.48 & 0.63 \\
3 days & 8.01 & 5.96 & 7.76 & 5.69 & 0.86 \\
5 days & 9.46 & 7.69 & 9.30 & 6.86 & 0.79 \\
7 days & 14.45 & 10.77 & 10.60 & 9.67 & 1.79 \\
Cooking loss (\%) & 31.89 & 32.11 & 30.12 & 29.75 & 1.07 \\
M. longissimus dorsi area (cm $\left.{ }^{2}\right)$ & 41.67 & 43.94 & 41.62 & 44.85 & 2.70 \\
\hline
\end{tabular}

1) NC: Antibiotic free diet; PC: NC diet included 0 6 weeks 44 ppm/ 6 10 weeks 22 ppm of tylosin; RE1: NC diet + RE 100 ppm; RE2: NC diet + RE 200 ppm.

${ }^{2)}$ Pooled standard error.

a,b Means in the same row with difference superscripts differ $(P<0.05)$.

구와 비교하여 높게 나타났으며 $(P<0.05), \mathrm{a}^{*}$ 값 은 $\mathrm{PC}$ 처리구가 $\mathrm{RE} 1$ 처리구와 비교하여 유의적 으로 높았다 $(P<0.05)$. 육내 $\mathrm{pH}$ 는 $\mathrm{RE} 1$ 처리구가 $\mathrm{RE} 2$ 처리구와 비교하여 높았으나 $(P<0.05)$, TBARS, 보수력, 드립감량, 가열감량 및 등심단 면적은 처리구간에 유의적인 차이가 없었다 $(P>0.05)$.

명도 (Lightness; $\mathrm{L}^{*}$ )는 육의 창백성을 측정하 는 요소로서 Goldspi근장의nk와 McLoughlin (1964)은 일부의 근장단백질이 침전하여 육색에 영향을 미치며, 이 침전된 단백질이 일반적인 붉은색을 가리게 되어 육색이 창백하게 된다고 하였다.

Wan 등(1997)의 연구에서는 희토가 돼지의 육질을 개선한다고 하였다. 본 시험에서도 희
토 첨가시 명도가 향상되는 결과를 보였으며, 유의적인 차이는 없었으나, 대조구에 비해 보 수력이 높고 드립 감량이 낮은 경향을 보였다. 또한, 송 (2007)의 연구결과에서도 비육돈에 희 토를 $100 \mathrm{ppm}$ 첨가 시 대조구와 비교하여 육의 명도와 적색도 및 보수력이 높게 나타났으며, 드립감량은 대조구보다 현저히 낮은 값을 나타 내었다고 하였다. 명도에 있어서는 본 시험과 유사한 결과를 보였으나, 적색도에 있어서는 상이한 결과를 나타내었다.

육색은 $\mathrm{pH}$, 온도, 도축 전 스트레스와 같은 환경적인 복합적 요인에 의해서 변이가 발생할 수 있으므로(Krzywicki, 1982), 희토 첨가에 의 한 육색의 변화에 대해서는 추가적인 연구가 필요할 것으로 사료된다. 
Table 9. Effects of RE supplementation on fatty acid composition of intramuscular fat

\begin{tabular}{|c|c|c|c|c|c|}
\hline \multirow{2}{*}{ Fatty acid (\%) } & \multicolumn{5}{|c|}{ Intramuscular fat } \\
\hline & $\mathrm{NC}^{1)}$ & $\mathrm{PC}^{1)}$ & $\mathrm{RE}^{1)}$ & $\mathrm{RE}^{1)}$ & $\mathrm{SE}^{2)}$ \\
\hline Myristic acid (C14:0) & $2.43^{\mathrm{ab}}$ & $2.30^{\mathrm{b}}$ & $2.23^{\mathrm{b}}$ & $2.53^{\mathrm{a}}$ & 0.07 \\
\hline Palmitic acid (C16:0) & 21.01 & 20.98 & 21.15 & 20.80 & 0.20 \\
\hline Stearic acid (C18:0) & 10.23 & 10.00 & 10.08 & 10.27 & 0.21 \\
\hline Arachidic acid (C20:0) & $0.92^{\mathrm{a}}$ & $0.87^{\mathrm{a}}$ & $0.69^{\mathrm{b}}$ & $0.72^{\mathrm{b}}$ & 0.02 \\
\hline Total SFA & 34.59 & 34.16 & 34.14 & 34.32 & 0.23 \\
\hline Myristoleic acid (C14:1n5) & 0.06 & 0.14 & 0.06 & 0.05 & 0.03 \\
\hline Palmitoleic acid (C16:1n7) & 3.07 & 3.04 & 3.16 & 3.25 & 0.08 \\
\hline Oleic acid (C18:1n9) & 41.08 & 41.15 & 41.30 & 41.78 & 0.18 \\
\hline 11-Eicosenoic acid (C20:1n9) & 0.72 & 0.73 & 0.73 & 0.71 & 0.04 \\
\hline Erucic acid (C22:1n9) & $0.44^{\mathrm{a}}$ & $0.39^{b}$ & $0.41^{\mathrm{b}}$ & $0.47^{\mathrm{a}}$ & 0.01 \\
\hline Total MUFA & $45.37^{\mathrm{b}}$ & $45.44^{\mathrm{b}}$ & $45.66^{\mathrm{b}}$ & $46.25^{\mathrm{a}}$ & 0.17 \\
\hline Linoleic acid (C18:2) & 12.00 & 12.09 & 12.02 & 12.12 & 0.13 \\
\hline 11,14-Eicosadienoic acid (C20:2n6) & 0.70 & 0.67 & 0.75 & 0.70 & 0.03 \\
\hline Arachidonic acid (C20:4n6) & $0.15^{\mathrm{b}}$ & $0.14^{\mathrm{b}}$ & $0.20^{\mathrm{a}}$ & $0.18^{\mathrm{ab}}$ & 0.01 \\
\hline Total $\omega 6$ & 12.85 & 12.90 & 12.97 & 13.00 & 0.12 \\
\hline Linolenic acid (C18:3n3) & 0.40 & 0.42 & 0.44 & 0.43 & 0.02 \\
\hline Total $\omega 3$ & 0.40 & 0.42 & 0.44 & 0.43 & 0.02 \\
\hline Total PUFA & 13.29 & 13.27 & 13.41 & 13.43 & 0.11 \\
\hline Total UFA & $58.68^{\mathrm{b}}$ & $58.77^{\mathrm{b}}$ & $59.08^{\mathrm{ab}}$ & $59.68^{\mathrm{a}}$ & 0.21 \\
\hline Total UFA/SFA & 1.70 & 1.72 & 1.73 & 1.74 & 0.01 \\
\hline
\end{tabular}

${ }^{1)}$ NC: Antibiotic free diet; PC: NC diet included 0 6 weeks 44ppm/ 6 10 weeks 22ppm of tylosin; RE1: NC diet + RE 100ppm; RE2: NC diet + RE 200ppm.

${ }^{2)}$ Pooled standard error.

${ }^{\mathrm{a}, \mathrm{b}}$ Means in the same row with difference superscripts differ $(P<0.05)$.

본 시험의 결과 희토를 첨가한 처리구에서 명도가 높게 나타났으나, 희토 $100 \mathrm{ppm}$ 첨가 처 리구는 적색도가 낮은 결과를 보였다.

\section{5. 육의 지방산 조성}

비육돈에 있어서 희토의 첨가가 근내 지방 및 등지방 내 지방산 조성에 미치는 영향은 Table 9와 Table 10에 나타내었다. 근내 지방의 지방산 함량에서 Myristic acid는 RE2 처리구가 $\mathrm{PC}$ 및 RE1처리구와 비교하여 유의적으로 높
게 나타났으며 $(P<0.05)$, Arachidic acid는 NC 및 $\mathrm{PC}$ 처리구가 희토를 첨가한 RE1 및 $\mathrm{RE} 2$ 처리 구와 비교하여 높았다 $(P<0.05)$. Erucic acid는 $\mathrm{NC}$ 및 RE2 처리구가 PC 및 RE1처리구와 비교 하여 높았으며 $(P<0.05)$, total monounsaturated fatty acids(MUFA)는 RE2 처리구가 다른 처리 구와 비교하여 높은 함량을 나타내었다 $(P<$ 0.05). Arachidonic acid는 RE1처리구가 NC 및 $\mathrm{PC}$ 처리구와 비교하여 높게 나타났으며 $(P<$ $0.05)$, total unsaturated fatty acid(UFA)는 RE2 처리구가 $\mathrm{PC}$ 처리구와 비교하여 높았다 $(P<$ 
Table 10. Effects of RE supplementation on fatty acid composition of back fat

\begin{tabular}{|c|c|c|c|c|c|}
\hline \multirow{2}{*}{ Fatty acid (\%) } & \multicolumn{5}{|c|}{ Back bat } \\
\hline & $\mathrm{NC}^{1)}$ & $\mathrm{PC}^{1)}$ & $\mathrm{RE}^{1)}$ & $\mathrm{RE}^{1)}$ & $\mathrm{SE}^{2)}$ \\
\hline Myristic acid (C14:0) & 1.70 & 1.48 & 1.70 & 1.44 & 0.08 \\
\hline Palmitic acid (C16:0) & 21.28 & 21.21 & 21.75 & 21.22 & 0.27 \\
\hline Stearic acid (C18:0) & $10.94^{\mathrm{a}}$ & $10.99^{\mathrm{a}}$ & $9.95^{\mathrm{b}}$ & $10.65^{\mathrm{a}}$ & 0.16 \\
\hline Arachidic acid (C20:0) & $0.90^{\mathrm{a}}$ & $0.91^{\mathrm{a}}$ & $0.78^{\mathrm{ab}}$ & $0.73^{\mathrm{b}}$ & 0.04 \\
\hline Total SFA & $34.46^{\mathrm{ab}}$ & $34.99^{\mathrm{a}}$ & $34.17^{\mathrm{b}}$ & $34.03^{b}$ & 0.22 \\
\hline Myristoleic acid (C14:1n5) & 0.05 & 0.06 & 0.05 & 0.06 & 0.01 \\
\hline Palmitoleic acid (C16:1n7) & $2.62^{\mathrm{b}}$ & $2.65^{\mathrm{b}}$ & $2.79^{\mathrm{ab}}$ & $3.00 \mathrm{a}$ & 0.09 \\
\hline Oleic acid (C18:1n9) & 41.93 & 41.98 & 42.16 & 41.97 & 0.18 \\
\hline 11-Eicosenoic acid (C20:1n9) & 0.77 & 0.75 & 0.78 & 0.78 & 0.04 \\
\hline Erucic acid (C22:1n9) & 0.49 & 0.49 & 0.51 & 0.47 & 0.03 \\
\hline Total MUFA & 46.35 & 46.06 & 46.29 & 46.28 & 0.21 \\
\hline Linoleic acid (C18:2) & 12.79 & 12.74 & 12.99 & 12.98 & 0.19 \\
\hline 11,14-Eicosadienoic acid (C20:2n6) & 0.68 & 0.70 & 0.68 & 0.70 & 0.03 \\
\hline Arachidonic acid (C20:4n6) & $0.18^{\mathrm{b}}$ & $0.18^{\mathrm{b}}$ & $0.21^{\mathrm{b}}$ & $0.28^{\mathrm{a}}$ & 0.02 \\
\hline Total $\omega 6$ & 13.64 & 13.62 & 13.87 & 13.96 & 0.18 \\
\hline Linolenic acid (C18:3n3) & $0.79^{\mathrm{b}}$ & $0.73^{\mathrm{b}}$ & $0.89^{\mathrm{a}}$ & $0.87^{\mathrm{a}}$ & 0.03 \\
\hline Total $\omega 3$ & $0.79^{b}$ & $0.73^{\mathrm{b}}$ & $0.89^{\mathrm{a}}$ & $0.87^{\mathrm{a}}$ & 0.03 \\
\hline Total PUFA & 14.43 & 14.34 & 14.76 & 14.83 & 0.18 \\
\hline Total UFA & 60.77 & 60.41 & 61.04 & 61.11 & 0.22 \\
\hline Total UFA/SFA & $1.76^{\mathrm{ab}}$ & $1.73^{\mathrm{b}}$ & $1.79^{\mathrm{a}}$ & $1.80^{\mathrm{a}}$ & 0.02 \\
\hline
\end{tabular}

0.05). Total saturated fatty acid(SFA) 및 Total $\mathrm{UFA} / \mathrm{SFA}$ 는 처리구간에 유의적인 차이가 없었 다 $(P>0.05)$. 등지방 내 지방산 함량에서 Stearic acid는 RE1 처리구가 다른 처리구와 비교하여 낮게 나타났으며 $(P<0.05)$, Arachidic acid는 NC 및 $\mathrm{PC}$ 처리구가 RE2 처리구와 비교하여 높았다 $(P<0.05)$. Total SFA는 $\mathrm{PC}$ 처리구가 $\mathrm{RE} 1$ 및 $\mathrm{RE} 2$ 처리구와 비교하여 높았다 $(P<0.05)$. Palmitoleic acid는 RE2 처리구가 NC 및 PC처리구와 비교하여 높게 나타났으며 $(P<0.05)$, Arachidonic acid는 RE2 처리구가 다른 처리구와 비교하여 가장 높았다 $(P<0.05)$. Linolenic acid 및 Total $\omega$ 3는 RE1 및 RE2 처리구가 $\mathrm{NC}$ 및 $\mathrm{PC}$ 처리구와 비교하여 높았고 $(P<0.05)$, total $\mathrm{UFA}$ 는 처리구 간에 유의적인 차이가 없었다 $(P>0.05)$. Total $\mathrm{UFA} / \mathrm{SFA}$ 는 RE1 및 RE2 처리구가 PC 처리구와 비교하여 높게 나타났다 $(P<0.05)$.

Hilditch 등 (1984)은 돈육 지질 조성에 관한 연구에서 주요 지방산은 포화지방산에서 palmitic acid가 불포화 지방산에서는 oleic acid의 함량 
이 가장 높았다고 보고하여 본 시험과 일치하 였다.

일반적으로 인체건강과 관련된 동맥경화증, 고혈압 등의 성인병 예방에 유익한 지방산은 불포화지방산 비율이 높고 포화지방산의 비율 이 낮을수록 좋다고 하였으며 (Decker와 Shantha, 1994), 이와 같은 견해에 따라서 Sturdivant 등 (1992)은 건강을 위해 palmitic acid 같은 포화지 방산을 oleic acid로 대체한 식육을 섭취할 것을 권장한 바 있다. 송 (2007)은 비육돈에 희토의 첨가시 포화지방산 비율은 낮았으며, 불포화지 방산의 비율은 높게 나타났다고 보고하여, 본 시험과 유사한 결과를 나타내었다. 세포의 막 과 세포내 막성분은 많은 인지질 (phospholipids) 로 구성되어 있으며, 이는 많은 불포화지방산 을 함유하고 있다. 희토는 이러한 불포화지방 산 불안정에 따른 산패를 억제하여 세포막을 안정화 하는 효과가 있다 $(\mathrm{Hu}$ 와 $\mathrm{Ye}, 1996)$.

본 시험의 결과에서 희토의 첨가는 포화지방 산 비율이 낮게 나타났으며, 불포화지방산의 비 율이 높은 결과를 나타내어 돈육의 지방산 조 성에 긍정적인 영향을 미치는 것으로 사료되나, 희토 첨가가 지방산 조성에 미치는 영향에 대 한 연구가 전무한 실정이므로 이에 대한 추가 적인 연구가 진행되어야 할 것으로 사료된다.

\section{6. 분내 유해가스 함량}

비육돈에 있어서 희토의 첨가가 분내 유해가
스 함량에 미치는 영향은 Table 11에 나타내었 다. 암모니아 $\left(\mathrm{NH}_{3}\right)$ 는 희토를 첨가한 $\mathrm{RE1}$ 및 $\mathrm{RE} 2$ 처리구가 NC 및 $\mathrm{PC}$ 처리구와 비교하여 유 의적으로 낮은 함량을 나타내었다 $(P<0.05)$. 휘 발성 지방산 중 Acetic acid는 RE1 처리구가 $\mathrm{RE} 2$ 처리구와 비교하여 낮은 함량을 나타내었 으나 $(P<0.05)$, Mercaptans 및 황화수소의 함량 은 처리구간에 유의적인 차이가 없었다 $(P>$ 0.05).

암모니아태 질소 $\left(\mathrm{NH}_{3}-\mathrm{N}\right)$, 황화수소 및 휘발 성지방산 $(\mathrm{VFA})$ 과 같은 분내 유해가스는 양돈 생산 시설에서 돈사 내 공기를 오염시켜는 주 요 원인으로서 (Slanina, 1994) 암모니아는 가축 의 성장을 저해하는 역할을 하며 (Lin과 Visek, 1991), 높은 농도의 암모니아는 인체와 가축에 유해하다고 하였다 (Crook 등, 1991; Busse, 1993).

희토원소 중 $\mathrm{La}^{3+}$ 의 농도가 $10^{-4} \sim 10^{-2}$ 일 때 는 박테리아, 균류, 효모의 성장을 억제한다고 하였으며 (Muroma, 1958), 희토의 첨가는 총균 수와 E. coli의 증식을 억제하는 효과 등 장내 미생물의 변화를 나타내었다(송, 2004; 송과 박, 2007). 본 시험에서 $100 \mathrm{ppm}$ 의 희토 첨가시 분내 암모니아 및 Acetic acid가 감소하였으며, 희토 첨가시 E. coli의 세포 보호막을 파괴하여 병원성 세균을 괴멸시켜(Liu 등, 2004), 장내 유해미생물의 번식을 억제하여 미생물 균총을 변화시킴으로서 유해 가스 발생량이 감소한 것 으로 사료된다.

Table 11. Effects of RE supplementation on change in noxious gas emission compounds in finishing pigs

\begin{tabular}{lccccc}
\hline \multicolumn{1}{c}{ Items $(\mathrm{ppm})$} & $\mathrm{NC}^{1)}$ & $\mathrm{PC}^{1)}$ & $\mathrm{RE}^{1)}$ & $\mathrm{RE2}^{1)}$ & $\mathrm{SE}^{2)}$ \\
\hline \hline $\mathrm{NH}_{3}$ & $6.67^{\mathrm{a}}$ & $7.11^{\mathrm{a}}$ & $3.33^{\mathrm{b}}$ & $2.34^{\mathrm{b}}$ & 0.50 \\
$\mathrm{R} \cdot \mathrm{SH}$ & 27.22 & 26.11 & 20.00 & 34.33 & 6.31 \\
$\mathrm{H}_{2} \mathrm{~S}$ & 93.33 & 64.44 & 83.35 & 98.31 & 12.06 \\
Acetic acid & $4.44^{\mathrm{ab}}$ & $4.67^{\mathrm{ab}}$ & $1.30^{\mathrm{b}}$ & $8.03^{\mathrm{a}}$ & 1.07 \\
\hline
\end{tabular}

\footnotetext{
${ }^{1)}$ NC: Antibiotic free diet; PC: NC diet included 0 6 weeks 44 ppm/ 6 10 weeks 22 ppm of tylosin; RE1: NC diet + RE 100 ppm; RE2: NC diet + RE 200 ppm.

2) Pooled standard error.

${ }^{\mathrm{a}, \mathrm{b}}$ Means in the same row with difference superscripts differ $(P<0.05)$.
} 
결론적으로, 본 시험에서 비육돈에 희토의 첨가는 영양소 소화율, $\mathrm{WBC}$ 함량, 육내 $\mathrm{pH}$, 육색, 지방산조성 및 분내 유해가스 함량에 영 향을 미치는 것으로 사료된다.

$$
\text { IV. 요 약 }
$$

본 연구는 희토의 첨가가 비육돈의 생산성, 면역관련 혈액학적 지표, 육질특성 및 분내 유 해가스발생 함량에 미치는 영향에 대해 알아보 기 위하여 시험을 실시하였다. 3원 교잡종 비 육돈 64두를 공시하였으며, 시험 개시시 체중 이 $65.42 \pm 1.16 \mathrm{~kg}$ 이었고, 10 주간 사양시험을 실시하였다. 시험설계는 1) Antibiotic free diet (NC), 2) NC diet +6 weeks $44 \mathrm{ppm}$ of tylosin / 4 weeks $22 \mathrm{ppm}$ of tylosin (PC) 3) $\mathrm{NC}$ diet +100 ppm of RE (RE1) 및 4) NC diet $+200 \mathrm{ppm}$ of $\mathrm{RE}$ (RE2)로 4개 처리를 하여 처리당 4반복, 반 복당 4 두씩 완전임의 배치하였다. 사양시험 기 간 동안 일당증체량, 일당사료섭취량 및 사료 효율은 처리구간에 유의적인 차이가 없었다 $(P>$ 0.05). 건물 및 질소 소화율은 $\mathrm{RE} 2$ 처리구가 다 른 처리구와 비교하여 높게 나타났으며 $(P<$ 0.05). 에너지소화율은 RE2 처리구가 NC 및 $\mathrm{RE} 1$ 처리구와 비교하여 높은 소화율을 나타내 었다 $(P<0.05) . \mathrm{WBC}$ 수준은 6주에서 $\mathrm{RE} 1$ 처리 구가 $\mathrm{NC}$ 및 $\mathrm{RE} 2$ 처리구와 비교하여 높은 함량 을 나타내었다 $(P<0.05)$. 배최장근의 명도를 나 타내는 $\mathrm{L}^{*}$ 값은 희토를 첨가한 $\mathrm{RE} 1$ 및 $\mathrm{RE} 2$ 처 리구가 $\mathrm{NC}$ 처리구와 비교하여 높게 나타났으나 $(\mathrm{P}<0.05), \mathrm{a}^{*}$ 값은 $\mathrm{PC}$ 처리구가 $\mathrm{RE} 1$ 처리구와 비 교하여 유의적으로 높았다 $(P<0.05)$. 근내지방 내 지방산 조성에 있어서 total MUFA는 RE2 처리구가 다른 처리구와 비교하여 높은 함량을 나타내었으며 $(P<0.05)$, total UFA는 RE2 처리구 가 $\mathrm{PC}$ 처리구와 비교하여 높았다 $(P<0.05)$. 등지 방 내 지방산 조성에 있어서 Total SFA는 PC 처리구가 희토를 첨가한 $\mathrm{RE} 1$ 및 $\mathrm{RE} 2$ 처리구와 비교하여 높은 함량은 나타내었다 $(P<0.05)$. Total UFA/SFA는 희토를 첨가한 RE1 및 RE2 처리구가 PC 처리구와 비교하여 높게 나타났다 $(P<0.05)$. 분내 유해가스 물질의 발생 함량에
있어서 암모니아 $\left(\mathrm{NH}_{3}\right)$ 는 희토를 첨가한 $\mathrm{RE} 1$ 및 $\mathrm{RE} 2$ 처리구가 $\mathrm{NC}$ 및 $\mathrm{PC}$ 처리구와 비교하여 낮은 함량을 나타내었다 $(P<0.05)$. 결론적으로, 본 시험의 결과 비육돈에 희토의 첨가는 영양 소 소화율, 육질특성, 지방산조성 및 분내 유해 가스 함량에 영향을 미치는 것으로 사료된다.

\section{V. 인 용 문 헌}

1. AOAC. 1995. Official method of analysis. 16th ed. Association of official Analytical Chemists. Washington, D. C.

2. Böhme, H., Fleckenstein, J., Hu, Z. and Schnug, E. 2002. Bilanzversuche zum Einsatz von Seltenen Erden in der Schweinemast. In: 114. VDLUFA Kongress, Leipzig, 16-20.

3. Borger, C. 2003. Alternative Methoden in der Schweinemast. Untersuchungen zum leistungssteigernden Potential Seltener Erden und zur jodanreicherung im Gewebe durch die Verfütterung von Meeresalgen. Dissertation med. Vet., LudwingMaximilians-Universität, München.

4. Busse, F. W. 1993. Comparison measurements of the house climate in swine stables with and without respiratory diseases or cannibalism. In: Livestock Environment (Collins E. and Boon C. eds). Fourth International Symposium, University of Warwick, Coventry, England. ASAE, St. Joseph, MI. pp: 904-908.

5. Cheng, Q., Gao, J., Jing, B., Yuan, D. and Pong, X. 1994. The apparent digestibility of rare earth elements and their effect on crude protein and fat digestibility in pigs. Jiangsu Agriculture Science (Chinese) 1:59-61.

6. Crook, B., Robertson, J. F., Glass, S. A. T., Botheroyd, M., Lacey, J. and Topping, M. D. 1991. Airborne dust, ammonia, microorganisms and antigens in pig confinement houses and the repiatory health of exposed farm-workers. American Industrial Hygiene Association Journal. 52:271-279.

7. Decker, E. A. and Shantha, N. C. 1994. 
Concentration of the anticarcinogen, conjugated linoleic acid in beef. Meat Focus International. 3: 61.

8. Deveci, M., Eski, M., Sengezer, M. and Kissa, U. 2000. Effects of Cerium nitrate bathing and prompt burn wound excision on IL-6 and TNFalpha levels in burned rats. Burns 26:41-45.

9. Duncan, D. B. 1955. Multiple range and multiple F tests. Biometrics. 11:1-14.

10. Eisele, N. 2003. Untersuchungen zum Einsatz Seltener Erden als Leistungsförderer beim Schwein. Dissertation med. Vet., LudwingMaximilians-Universität, München.

11. Folch, J., Lees, M. and Sloane-Stanley, G. H. 1957. A simple method for the isolation and purification of total lipid from animal tissues. J. Biol. Chem. 226:497-509.

12. Goldspink, G. and McLoughlin, J. V. 1964. Studies on pig muscle. 3. The effect of temperature on the solubility of the sarcoplasmic proteins in relation th color changes in post-rigor muscle. Ir. J. Agric. Res. 3:9.

13. He, M. L., Drnz, D. and Rambeck, W. A. 2001. Study on the performance enhancing effect of rare earth elements in growing and fatting pigs. J. Anim. Phsyiology A. Anim. Nutr. 85:263-270.

14. He, M. L., Wang, Y. Z., Xu, Z. R., Chen, M. L. and Rambeck, W. A. 2003. Effect of dietary rare earth elements on growth performance and blood parameters of rats. J. Anim. Physiol. A. Anim. Nutr. 87:229-235.

15. Hilditch, T. P., Jones, E. C. and Rhead, A. J. 1984. The body fats of the han. J. Biochem 28: 786-792.

16. Hirano, S. and Suzuki, K. T. 1996. Environ. Health Perspect. 104(suppl. 1), 85-95.

17. Hofmann, K., Hamm, R. and Bluchel, E. 1982. New information on the determination of water binding in meat by the filter paper press method. Fleischwirtsch 62:87-94.

18. $\mathrm{Hu}, \mathrm{Q} . \mathrm{H}$. and Ye, Z. J. 1996. Physiological effects of rare earth elements on plants. Chinese
Plant Physiology Communication, 32(4):296-300.

19. Kessler, J. 2004. Lanthanoide-Wachstumsförder mit Zukunft. In: Schweinehaltung, 04. 255, Sursee/ Oberkirch 22-23.

20. Lin, H. C. and Visek, W. J. 1991. Colon mucosal cell damage by ammonia in rats. J. Nutr. 121: 887-893.

21. Liu, P., Liu, Y., Lu, Z., Zu, J., Zhu, J., Dong, J., Pang, D., Shen, P. and Pang, S. 2004. Study on biological effect of $\mathrm{La}^{3+}$ on Escherichia coli by atomic force microscopy. J Inorganic BioChemistry. 98:68-72.

22. Lu, K. W. and Yang, W. Z. 1996. Effects of rare earth elements on availability of energy and amino acids in broiler. Acta. Agric. Shanghai (Chinese) 12:78-82.

23. Muroma A. 1958. Ann Med Exp Biol Fenn 36(Suppl) 6:1-54.

24. National Pork Producers Council. 2000. Pork Composition and Quality Assessment Procedures. National Pork Producers Council, P.O. Box 10383, Des Moines, Iowa 50306.

25. NRC. 1998. Nutrient Requirements of swine. National Research Council, Academy Press.

26. SAS. 1996. SAS user's guide: Statisics, SAS Inst, Inc., Cary, NC.

27. Shang, L. and Liu, X. 1997. Rare earths as a feed additive for poultry. World's Poultry Science Journal 53:369-379.

28. Slanina, S. 1994. Forest dieback and ammonia-a typical Dutch problem. Chemistry International. 16:2-3.

29. Sturdivant, C. A., Lunt, D. K., Smith, G. C. and Smith. S. B. 1992. Fatty acid composition of sudcutaneous and intramuscular adipose tissues and $M$. longissimus dorsi of Wagyu cattle. Meat Science. 32:449-458.

30. Wan, Q., Jiang, W. Q., Luo, L. G., Liu, S., Ning, J. B. and Yuan, F. Z. 1997. Studies of rare earth additive for pig feed. Rare Earth 18(4):38-42.

31. Wang, M. Q. and $\mathrm{Xu}, \mathrm{Z}$. R. 2003. Effect of supplemental Lanthanum on the growth perfor- 
mance of pigs. Asian-Aust J. Anim. Sci. 16(9):1360-1363.

32. Wang, Q. 1989. Study of effects of rare earth added in the diet broiler chicken. Hunan Agricultural Science 1:28.

33. Witte, V. C., Krause, G. F. and Bailey, M. E. 1970. A new extraction method for determining 2thiobarbituric acid values for pork and beef during storage. J. Food Sci. 35:582-587.

34. Xie, K., Xing, Y., Zhang, J., Zhong, H., He, N. and Deng, S. 1991. Effects of rare earth elements of growth of broilers. Res. Agricult. Mod. (Chinese) 12:50-54.

35. 包玉民. 2001. 동물사육을 위한 희토의 연구 및 응용. 희토광물의 농업적 이용에 관한 국제심포 지엄. 전북대학교 농업과학기술연구소. pp: 9-13.

36. 胡忠澤. 1999. 稀土對生長猪日粮養分消化性的 影響. 飼料博覽 (Chinese). 11(1)

37. 紀雲晶. 2003. 稀土与人體健康, 希土的基礎知識 与應用, 中國稀土在腺. (Chinese) 3-5.
38. 吳 德. 2003. 稀土元素飼料添加劑的研究進展. 四川農業大學動物營養砾究所. 四川雅安, 中國. $1-4$.

39. 張宏江, 包玉敏, 張宇生. 2000. 稀土在農牧養殖 業中的應用. 包斗市金稀土生 物應用有限公司. (Chinese) 35-80.

40. 김 정. 2004. 자돈에 대한 희토급여 효과와 비 육돈의 도체성상에 미치는 영향. 전북대학교 석 사 학위논문.

41. 송태화. 2004. 희토의 쥐에 대한 급여효과와 미 생물 생장에 미치는 영향. 전북대학교 석사학위 논문.

42. 송태화. 2007. 희토의 급여가 육계와 돼지에 미 치는 영향. 전북대학교 박사학위논문.

43. 송태화, 박홍석. 2007. 희토와 클로르테트라시이 클인이 육계의 생산성 및 장내 미생물에 미치는 영향. 한국가금학회지 34(1):23-29.

(접수일자 : 2008. 1. 24. / 수정일자 : 2008. 6. 5. / 채택일자 : 2008. 8. 18.) 